\title{
Effect of Intercropping and Nitrogen Levels on the Growth Parameters of Legumes and Pearlmillet (Pennisetum typhoides L)
}

\author{
G. Jaya Prathiksha ${ }^{1 *}$ and Joy Dawson ${ }^{2}$ \\ Department of Agronomy, Naini Agricultural Institute, Sam Higginbottom University of \\ Agriculture, Technology and Sciences, Prayagraj, Uttar Pradesh - 211007, India \\ *Corresponding author
}

\section{Keywords \\ Cowpea, \\ Greengram, \\ Intercropping, \\ Nodules plant ${ }^{-1}$, \\ Pearlmillet and \\ plant height \\ Article Info \\ Accepted: \\ 04 August 2019 \\ Available Online: \\ 10 September 2019}

\section{A B S T R A C T}

This experiment focuses on the effect of intercropping and nitrogen levels on the growth parameters of pearlmillet and legumes. The initial plant population of pearlmillet was unaffected due to intercropping and the nitrogen levels. It was nearly equal in almost all the treatments. The plant height and the dry weight of pearlmillet was significantly influenced by the intercropping treatments and the different levels of nitrogen applied. The plant height and dry weight was maximum in the pure stand of pearlmillet $(167.6 \mathrm{~cm})$ dry weight $\left(103.0 \mathrm{~g} \mathrm{plant}^{-1}\right)$. The initial plant population of legumes also was unaffected with the intercropping and nitrogen levels. A slight higher plant population was recorded in the greengram sole crop and intercropped plots compared to cowpea at different intercrop combinations and nitrogen levels. The nodules plant ${ }^{-1}$ was maximum in the greengram plots when grown as sole and intercrops. Application of nitrogen at different levels showed significant effect on the nodules plant ${ }^{-1}$ of cowpea and greengram. The dry weight was maximum in greengram sole crop with $20 \mathrm{~kg} \mathrm{ha}^{-1}$ of $\mathrm{N}\left(12.36 \mathrm{~g} \mathrm{plant}^{-1}\right)$. It was confirmed in our study that the dry weight was higher in greengram compared to cowpea in the sole and intercrop treatments. Maximum pods plant-1 and grains pod-1was recorded in greengram compared to cowpea treatment combinations. The test weight was higher in the cowpea treatments than greengram.

\section{Introduction}

Pearl millet (Pennisetum typhoides L.) is one of the most important cereal crops grown in the tropical region. It ranks fourth after rice, wheat and sorghum and is grown in almost all the states of the country. Limited availability of land resources and the decline in the soil fertility has increased the importance of the ability of agriculture to sustain the increasing demand of the population both globally and locally. To counter the demand, we have to look for ways which enhance the use of currently available resources than in the past. Intercropping is one promising practise which is effective to augment the total productivity per unit area of the land per unit time by growing more than one crop in the same field with an objective of better utilization of environmental resources. The basic concept of intercropping involves growing together two or more crops with the assumption that two 
crops can exploit the environment better than one and ultimately produce higher yield (Reddy and Willy, 1981). Cereal-legume intercropping has attracted the attention of agronomists, possibly as a result of the established and theoretical advantages of intercropping systems (Ofori and Stern, 1978). Intercropping with legumes is a practice in which $\mathrm{N}$ fixed by latter enhances the qualitative and quantitative traits of the former to finally reach food security and sustainability (Swaminathan, 1998). Legumes such as cowpea, clusterbean and greengram are known to fix the atmospheric nitrogen with the help of rhizobium bacteria and it supplies the cereal crop with the required nitrogen. Our present study is conducted to evaluate the effect of intercropping legumes i.e., cowpea and greengram with pearlmillet and different nitrogen levels on the growth and yield of the legumes.

\section{Materials and Methods}

The field experiment was conducted at the Crop Research Farm of Naini Agricultural Institute, Sam Higginbottom University of Agriculture, Technology and Sciences during kharif 2017 and 2018. The experimental soil was sandy loam with $\mathrm{pH}$ (7.1 and 7.3), EC (0.80 and $\left.0.74 \mathrm{dSm}^{-1}\right)$, OC (0.48 and 0.45$)$, available $\mathrm{N}$ (108.0 and $\left.103.2 \mathrm{~kg} \mathrm{ha}^{-1}\right), \mathrm{P}(27.0$ and $25.2 \mathrm{~kg} \mathrm{ha}^{-1}$ ) and $\mathrm{K}$ (302.4 and $296.8 \mathrm{~kg}$ $\mathrm{ha}^{-1}$ ) during both the experimental years. The cultivars used for pearlmillet was KSBH-66, cowpea was Improved AK-57 and greengram was PDM-139 (Samrat). The experiment was laid down in a randomized block design with thirteen treatments. The two factors included fertility levels $[0$ (Pearlmillet), 20 (Cowpea/greengram), 40 (Pearlmillet) and 80 (Pearlmillet)] and intercrops [Pearlmillet (sole crop), pearlmillet + cowpea (1:1 ratio), pearlmillet + greengram $(1: 1$ ratio $)]$. The thirteen treatments were sole cropping of pearlmillet, cowpea, greengram and intercrops of cowpea and greengram with pearlmillet at 0 $\mathrm{kg} \mathrm{ha} \mathrm{h}^{-1}$ of nitrogen applied, sole crop of cowpea and greengram at $20 \mathrm{~kg} \mathrm{ha}^{-1}$ of $\mathrm{N}$, pure crop of pearlmillet, intercrops of cowpea and greengram each at 40 and $80 \mathrm{~kg} \mathrm{ha}^{-1}$. The rainfall received during the first experimental year was $444.2 \mathrm{~mm}$ spread over 27 days. During the second experimental year, the rainfall was $603.2 \mathrm{~mm}$ in 42 days during the crop duration. Pearlmillet was planted with spacing $45 \times 10 \mathrm{~cm}$, cowpea and greengram at $30 \times 10 \mathrm{~cm}$ in the plots where these were planted as sole crop. Basal dose with about $50 \%$ of recommended nitrogen and full dose of phosphorus and potassium were applied. In the plots with intercropping, in between two rows of pearlmillet, a row of cowpea/greengram was sown in 1:1 ratio. Nitrogen was applied as basal dose and split doses in the treatments with fertility level as 40 and $80 \mathrm{~kg} \mathrm{ha}^{-1}$ at 25 DAS and 55 DAS.

The data on the initial plant population was recorded using a quadrant of $1 \mathrm{~m}^{2}$ and the plants which fall within the quadrant are counted. The nodules plant ${ }^{-1}$ was counted by selecting five plants at random in each treatment. The plants were uprooted along with the ball of earth and washed gently under flowing water to remove the soil adhering to the root and root hairs and counted to find the number of nodules. The plant height was determined with the help of a meter scale measured upto the uppermost node. The plants from the borders of each treatment were uprooted and shade dried. They are then oven dried at $70^{\circ} \mathrm{C}$ till they attained constant weight. These samples were then weighed to determine the dry weight. Analysis of variance for randomized block design and significance of variance was tested by F-test (Gomez and Gomez, 1984). Critical difference for examining treatmental means for their significance was calculated at $5 \%$ significance. 


\section{Results and Discussion}

\section{Pearlmillet}

During the year 2017, the plant population (Table 1) was higher in the intercropped plot of greengram with nitrogen applied at $80 \mathrm{~kg}$ $\mathrm{ha}^{-1} \quad\left(\mathrm{~T}_{13}\right)$. This was followed by the intercropped plot of greengram with nitrogen at $40 \mathrm{~kg} \mathrm{ha}^{-1}\left(\mathrm{~T}_{10}\right)$. In 2018, the plant stand was highest in the greengram intercropped plot with nitrogen at $0 \mathrm{~kg} \mathrm{ha}^{-1}\left(\mathrm{~T}_{5}\right)$. The plant population in the plots with nitrogen applied at $0 \mathrm{~kg} \mathrm{ha}^{-1}$ in pure crop $\left(\mathrm{T}_{1}\right)$, intercrop with cowpea $\left(\mathrm{T}_{4}\right)$, application of nitrogen at $40 \mathrm{~kg}$ $\mathrm{ha}^{-1}$ in the pure stand $\left(\mathrm{T}_{8}\right)$, intercropped with cowpea $\left(\mathrm{T}_{9}\right)$ and greengram $\left(\mathrm{T}_{10}\right)$, nitrogen applied at $80 \mathrm{~kg} \mathrm{ha}^{-1}$ in pure crop $\left(\mathrm{T}_{11}\right)$, cowpea intercrop $\left(\mathrm{T}_{12}\right)$ was found to be equal.

At 80 DAS during the first experimental year, application of nitrogen at $80 \mathrm{~kg} \mathrm{ha}^{-1}$ for pure stand $\left(\mathrm{T}_{11}\right)$ recorded maximum plant height (Table 1). Next in the sequence was the application of nitrogen at $40 \mathrm{~kg} \mathrm{ha}^{-1}$ for pure stand $\left(\mathrm{T}_{8}\right)$, greengram intercropped plot with application of nitrogen at $80 \mathrm{~kg} \mathrm{ha}^{-1}\left(\mathrm{~T}_{13}\right)$, pure stand with nitrogen at $0 \mathrm{~kg} \mathrm{ha}^{-1}\left(\mathrm{~T}_{1}\right)$ and intercrop of greengram with $40\left(\mathrm{~T}_{10}\right)$ and 80 $\left(\mathrm{T}_{13}\right) \mathrm{kg} \mathrm{ha}$ of nitrogen applied were statistically at par with $\mathrm{T}_{11}$. During kharif 2018 also maximum plant height was recorded in $\mathrm{T}_{11}$. Next in the sequence was greengram intercropped plot with nitrogen at $80 \mathrm{~kg}^{-}$ ${ }^{1}\left(\mathrm{~T}_{13}\right)$, application of nitrogen at $40 \mathrm{~kg} \mathrm{ha}^{-1}$ in pure stand $\left(\mathrm{T}_{8}\right)$ and cowpea intercropped plot $\left(\mathrm{T}_{9}\right)$, nitrogen application at $0 \mathrm{~kg} \mathrm{ha}^{-1}$ in pure crop $\left(\mathrm{T}_{1}\right)$ and greengram intercropped plot with nitrogen applied at $40\left(\mathrm{~T}_{10}\right)$ and $0\left(\mathrm{~T}_{5}\right) \mathrm{kg}$ $\mathrm{ha}^{-1}$ and intercrop of cowpea with nitrogen at $80 \mathrm{~kg} \mathrm{ha}^{-1}\left(\mathrm{~T}_{12}\right)$ were statistically at par with $\mathrm{T}_{11}$.Higher plant height in sole cropping compared to intercropping plots might be attributed to higher cell elongation due to auxin accumulation in plants (Malik and Srivastava, 1982) and (Choudhary, 2009) moreover, light availability was comparatively lesser due to higher plant densities under sole crop.

In kharif 2017, the dry weight (Table 1) was recorded highest at 80 DAS and the treatment pure crop of pearlmillet $\left(\mathrm{T}_{11}\right)$ with nitrogen at $80 \mathrm{~kg} \mathrm{ha}^{-1}$. This was followed by pure stand at $40 \mathrm{~kg} \mathrm{ha}^{-1}\left(\mathrm{~T}_{8}\right)$ and was statistically at par with $\mathrm{T}_{11}$. During the second experimental year, maximum dry weight was recorded in $\mathrm{T}_{11}$. It was followed by greengram $\left(\mathrm{T}_{13}\right)$ and cowpea (T12) intercrop at $80 \mathrm{~kg} \mathrm{ha}^{-1}$ which were statistically at par with $\mathrm{T}_{11}$. A significant increase in plant dry matter at different stages of growth due to increase in nitrogen levels might be attributed to the effect of nitrogen in increasing the amount and efficiency of chlorophyll which influence the photosynthetic efficiency and formation of other nitrogen compounds (Karanjikar et al., 2018).

\section{Legumes}

It is evident from table 2 that the plant population remained unaffected by the different treatments. In 2017, it can be observed that the population of greengram $\left(\mathrm{T}_{10}\right.$ and $\left.\mathrm{T}_{13}\right)$ was slightly higher than cowpea $\left(\mathrm{T}_{9}\right.$ and $\left.\mathrm{T}_{12}\right)$ in the plots which were intercropped with pearl millet and nitrogen was applied at $40 \mathrm{~kg} \mathrm{ha}^{-1}$ and $80 \mathrm{~kg} \mathrm{ha}^{-1}$, respectively. But in plots where nitrogen applied was $0 \mathrm{~kg} \mathrm{ha}^{-1}$ and intercropped with pearl millet, the plant population of cowpea $\left(\mathrm{T}_{4}\right)$ and greengram $\left(\mathrm{T}_{5}\right)$ was found to be equal. During 2018, a slightly higher population was observed in all the treatments compared to the first experimental year. Equal population was observed in the plots of pure crop of cowpea $\left(T_{2}\right)$, greengram $\left(T_{3}\right)$, intercrop of cowpea $\left(\mathrm{T}_{4}\right)$ and greengram $\left(\mathrm{T}_{5}\right)$ with nitrogen applied at $0 \mathrm{~kg} \mathrm{ha}^{-1}$, pure crop of greengram with nitrogen applied at $20 \mathrm{~kg} \mathrm{ha}^{-1}$ $\left(\mathrm{T}_{7}\right)$, intercrops of greengram $\left(\mathrm{T}_{10}\right)$ and 
cowpea $\left(\mathrm{T}_{9}\right)$ at $40 \mathrm{~kg} \mathrm{ha}^{-1}$ and greengram intercropped plot with nitrogen at $80 \mathrm{~kg} \mathrm{ha}^{-1}$ $\left(\mathrm{T}_{13}\right)$.

During kharif 2017, the nodules plant ${ }^{-1}$ at 60 DAS (Table 2), was recorded highest in the plots of pure stand of greengram at $20 \mathrm{~kg} \mathrm{ha}^{-1}$ $\left(\mathrm{T}_{7}\right)$ and intercropping of greengram with nitrogen applied at $40 \mathrm{~kg} \mathrm{ha}^{-1}\left(\mathrm{~T}_{10}\right)$. Next in the sequence was greengram intercrop with nitrogen applied at $80 \mathrm{~kg} \mathrm{ha}^{-1}\left(\mathrm{~T}_{13}\right)$, intercropping of cowpea with nitrogen applied at $40\left(\mathrm{~T}_{9}\right)$ and $80 \mathrm{~kg} \mathrm{ha}^{-1}\left(\mathrm{~T}_{12}\right)$ and sole crop of cowpea at $20 \mathrm{~kg} \mathrm{ha}^{-1}\left(\mathrm{~T}_{6}\right)$, pure stand of greengram $\left(\mathrm{T}_{3}\right)$ and cowpea $\left(\mathrm{T}_{2}\right)$ and intercropped plots of greengram at $0 \mathrm{~kg} \mathrm{ha}^{-}$ ${ }^{1}\left(\mathrm{~T}_{5}\right)$ of nitrogen applied. During the second experimental year, at 60 DAS, highest number of nodules was observed in pure crop of cowpea at $20 \mathrm{~kg} \mathrm{ha}^{-1}\left(\mathrm{~T}_{6}\right)$. This was followed by pure crop of greengram at $20 \mathrm{~kg} \mathrm{ha}^{-1}\left(\mathrm{~T}_{7}\right)$, cowpea at $0 \mathrm{~kg} \mathrm{ha}^{-1}\left(\mathrm{~T}_{2}\right)$, greengram intercropped plot with nitrogen applied at 80 $\left(\mathrm{T}_{13}\right)$ and $40\left(\mathrm{~T}_{10}\right) \mathrm{kg} \mathrm{ha}^{-1}$, cowpea intercrop at $80 \mathrm{~kg} \mathrm{ha}^{-1}\left(\mathrm{~T}_{12}\right)$ and greengram sole crop at 0 $\mathrm{kg} \mathrm{ha}^{-1}\left(\mathrm{~T}_{3}\right)$ and were statistically at par with $\mathrm{T}_{7}$.

In kharif 2017, at 60 DAS (Table 2), the dry weight was the highest in pure crop of greengram with nitrogen applied at $20 \mathrm{~kg} \mathrm{ha}^{-1}$ $\left(T_{7}\right)$. Next in the sequence was pure crop of cowpea with nitrogen applied at $20 \mathrm{~kg} \mathrm{ha}^{-1}$ $\left(\mathrm{T}_{6}\right)$, greengram $\left(\mathrm{T}_{13}\right)$ and cowpea $\left(\mathrm{T}_{12}\right)$ intercropped plot with nitrogen applied at 80 $\mathrm{kg} \mathrm{ha}{ }^{-1}$, greengram intercropped plot with nitrogen at $40 \mathrm{~kg} \mathrm{ha}^{-1}\left(\mathrm{~T}_{10}\right)$, pure crop of greengram $\left(\mathrm{T}_{3}\right)$ and cowpea at $0 \mathrm{~kg} \mathrm{ha}^{-1}\left(\mathrm{~T}_{2}\right)$, intercrop of greengram with nitrogen applied at $0 \mathrm{~kg} \mathrm{ha}^{-1}\left(\mathrm{~T}_{5}\right)$ and cowpea intercropped plot at $40 \mathrm{~kg} \mathrm{ha}^{-1}\left(\mathrm{~T}_{9}\right)$ were found to be statistically at par with $\mathrm{T}_{7}$. In the second experimental year, at 60 DAS, highest dry weight was recorded in pure crop of cowpea with nitrogen application of $20 \mathrm{~kg} \mathrm{ha}^{-1}\left(\mathrm{~T}_{6}\right)$. It was followed by pure crop of greengram with $20 \mathrm{~kg} \mathrm{ha}^{-1}$ of nitrogen $\left(\mathrm{T}_{7}\right)$, intercropping of greengram with nitrogen application of $80\left(\mathrm{~T}_{13}\right)$ and $40\left(\mathrm{~T}_{10}\right)$ $\mathrm{kg} \mathrm{ha}{ }^{-1}$, cowpea intercrop with nitrogen applied at $40 \mathrm{~kg} \mathrm{ha}^{-1}\left(\mathrm{~T}_{9}\right)$, pure crop of greengram with $0 \mathrm{~kg} \mathrm{ha}^{-1}$ of nitrogen $\left(\mathrm{T}_{3}\right)$ and intercrop of cowpea with nitrogen applied at $80 \mathrm{~kg} \mathrm{ha}^{-1}\left(\mathrm{~T}_{12}\right)$ were statistically at par with $\mathrm{T}_{6}$.

From table 3, for the year 2017, it can be concluded that the number of pods per plant were the highest in pure crop of greengram with nitrogen applied at $20 \mathrm{~kg} \mathrm{ha}^{-1}\left(\mathrm{~T}_{7}\right)$. It was followed by the application of nitrogen at $0 \mathrm{~kg}$ $\mathrm{ha}^{-1}$ in the pure stand of greengram $\left(\mathrm{T}_{3}\right)$ and was statistically at par with $\mathrm{T}_{7}$. Cowpea pure crop with nitrogen applied at $20 \mathrm{~kg} \mathrm{ha}^{-1}\left(\mathrm{~T}_{6}\right)$ recorded higher number of pods per plant compared to other treatments of cowpea. Equal number of pods per plant was observed in the plots of cowpea as pure stand $\left(\mathrm{T}_{2}\right)$, intercropped with nitrogen applied at $0\left(\mathrm{~T}_{4}\right)$, $40\left(\mathrm{~T}_{9}\right)$ and $80\left(\mathrm{~T}_{12}\right) \mathrm{kg} \mathrm{ha}^{-1}$. In the year 2018, the number of pods recorded was higher in both the intercrops compared to the first experimental year. Maximum number of pods per plant was recorded in the pure crop of greengram with nitrogen applied at $20 \mathrm{~kg} \mathrm{ha}^{-1}$ $\left(\mathrm{T}_{7}\right)$ and it was statistically significant compared to the rest of the treatments. The cowpea intercropped plots with nitrogen at 20 $\mathrm{kg} \mathrm{ha}^{-1}\left(\mathrm{~T}_{6}\right)$ recorded the highest pods per plant among the cowpea treatment

A perusal of the data of the year 2017 revealed that the maximum number of grains per pod (Table 3) was recorded in the treatment where nitrogen was applied at $20 \mathrm{~kg} \mathrm{ha}^{-1}$ in the pure stand of cowpea (T6) and greengram $\left(\mathrm{T}_{7}\right)$. Next in the sequence was greengram intercropped plots with nitrogen applied at 80 $\left(\mathrm{T}_{13}\right)$ and $40\left(\mathrm{~T}_{10}\right) \mathrm{kg} \mathrm{ha}^{-1}$, greengram sole crop with nitrogen at $0 \mathrm{~kg} \mathrm{ha}^{-1}\left(\mathrm{~T}_{3}\right)$ and intercropped plot of greengram with nitrogen applied at $0 \mathrm{~kg} \mathrm{ha}^{-1}\left(\mathrm{~T}_{5}\right)$ were statistically at par with $\mathrm{T}_{6}$ and $\mathrm{T}_{7}$. 


\section{Int.J.Curr.Microbiol.App.Sci (2019) 8(9): 440-447}

Table.1 Effect of nitrogen levels on growth parameters of pearl millet

\begin{tabular}{|c|c|c|c|c|c|}
\hline \multirow[t]{2}{*}{ Treatments } & $\begin{array}{c}\text { Initial } \\
\text { Plant Population } \\
\left(\text { No. } \mathrm{m}^{-2}\right)\end{array}$ & \multicolumn{2}{|c|}{$\begin{array}{l}\text { Plant Height } \\
\text { at } 80 \text { DAS }(\mathrm{cm})\end{array}$} & \multicolumn{2}{|c|}{$\begin{array}{l}\text { Dry weight } \\
\text { at } 80 \text { DAS }\left(\mathrm{g} \mathrm{plant}^{-1}\right)\end{array}$} \\
\hline & 2018 & 2017 & 2018 & 2017 & 2018 \\
\hline 1. Pearl millet with Nitrogen at $0 \mathrm{~kg} \mathrm{ha}^{-1}$ & 19 & 189.4 & 166.2 & 87.3 & 76.33 \\
\hline 2. Cowpea with Nitrogen at $0 \mathrm{~kg} \mathrm{ha}^{-1}$ & - & - & - & - & - \\
\hline 3. Greengram with with Nitrogen at $0 \mathrm{~kg} \mathrm{ha}^{-1}$ & - & - & - & - & - \\
\hline 4. Pearl millet + Cowpea (1:1 ratio) with Nitrogen at $0 \mathrm{~kg} \mathrm{ha}^{-1} 19$ & 19 & 183.2 & 162.0 & 76.6 & 70.3 \\
\hline 5. Pearl millet + Greengram (1:1 ratio) with Nitrogen at $0 \mathrm{~kg} \mathrm{ha}^{-1} 18$ & 20 & 185.4 & 164.6 & 82.0 & 74.4 \\
\hline 6. Cowpea with Nitrogen at $20 \mathrm{~kg} \mathrm{ha}^{-1}$ & - & - & - & - & - \\
\hline 7. Greengram with Nitrogen at $20 \mathrm{~kg} \mathrm{ha}^{-1}$ & - & - & - & - & - \\
\hline 8. Pearl millet with Nitrogen at $40 \mathrm{~kg} \mathrm{ha}^{-1}$ & 19 & 192.9 & 166.3 & 101.3 & 88.4 \\
\hline 9. Pearl millet + Cowpea (1:1 ratio) with Nitrogen at $40 \mathrm{~kg} \mathrm{ha}^{-1} 19$ & 19 & 184.3 & 166.3 & 79.8 & 81.6 \\
\hline 10. Pearl millet + Greengram (1:1 ratio) with Nitrogen at $40 \mathrm{~kg} \mathrm{ha}^{-1} 20$ & 19 & 188.2 & 165.3 & 87.3 & 85.2 \\
\hline 11. Pearl millet with Nitrogen at $80 \mathrm{~kg} \mathrm{ha}^{-1}$ & 19 & 196.5 & 167.6 & 103.0 & 100.0 \\
\hline 12. Pearl millet + Cowpea (1:1 ratio) with Nitrogen at $80 \mathrm{~kg} \mathrm{ha}^{-1} 19$ & 19 & 185.3 & 164.0 & 94.0 & 97.0 \\
\hline 13. Pearl millet + Greengram (1:1 ratio) with Nitrogen at $80 \mathrm{~kg} \mathrm{ha}^{-1} 20$ & 17 & 190.6 & 166.6 & 92.7 & 98.9 \\
\hline SE.m \pm & - & 3.6 & 1.52 .4 & 3.8 & \\
\hline $\mathrm{CD}(\mathrm{p}=0.05)$ & - & 10.7 & 4.6 & 7.2 & 11.3 \\
\hline
\end{tabular}




\section{Int.J.Curr.Microbiol.App.Sci (2019) 8(9): 440-447}

Table.2 Effect of nitrogen levels on growth parameters of cowpea and greengram

\begin{tabular}{|c|c|c|c|c|c|}
\hline \multirow[t]{2}{*}{ Treatments } & $\begin{array}{l}\text { Initial } \\
\text { Plant Population } \\
\left(\text { No. } \mathrm{m}^{-2}\right)\end{array}$ & \multicolumn{2}{|c|}{$\begin{array}{l}\text { Nodules plant }{ }^{-1} \\
\text { at } 60 \text { DAS (No.) }\end{array}$} & \multicolumn{2}{|c|}{$\begin{array}{l}\text { Dry weight } \\
\text { at } 60 \text { DAS }\left(\mathrm{g} \mathrm{plant}^{-1}\right)\end{array}$} \\
\hline & 2018 & 2017 & 2018 & 2017 & 2018 \\
\hline 1. Pearl millet with Nitrogen at $0 \mathrm{~kg} \mathrm{ha}^{-1}$ & - & - & - & - & - \\
\hline 2. Cowpea with Nitrogen at $0 \mathrm{~kg} \mathrm{ha}^{-1}$ & 29 & 19 & 25 & 11.43 & 7.11 \\
\hline 3. Greengram with with Nitrogen at $0 \mathrm{~kg} \mathrm{ha}^{-1}$ & 29 & 20 & 24 & 11.45 & 11.33 \\
\hline 4. Pearl millet + Cowpea (1:1 ratio) with Nitrogen at $0 \mathrm{~kg} \mathrm{ha}^{-1} 28$ & 29 & 11 & 20 & 10.11 & 6.26 \\
\hline 5. Pearl millet + Greengram ( $1: 1$ ratio) with Nitrogen at $0 \mathrm{~kg} \mathrm{ha}^{-1} 28$ & 29 & 18 & 15 & 11.14 & 6.69 \\
\hline 6. Cowpea with Nitrogen at $20 \mathrm{~kg} \mathrm{ha}^{-1}$ & 28 & 21 & 26 & 11.92 & 13.10 \\
\hline 7. Greengram with Nitrogen at $20 \mathrm{~kg} \mathrm{ha}^{-1}$ & 29 & 24 & 25 & 12.36 & 12.76 \\
\hline 8. Pearl millet with Nitrogen at $40 \mathrm{~kg} \mathrm{ha}^{-1}$ & - & - & - & - & - \\
\hline 9. Pearl millet + Cowpea (1:1 ratio) with Nitrogen at $40 \mathrm{~kg} \mathrm{ha}^{-1} 27$ & 29 & 21 & 21 & 11.05 & 10.38 \\
\hline 10. Pearl millet + Greengram (1:1 ratio) with Nitrogen at $40 \mathrm{~kg} \mathrm{ha}^{-1} 29$ & 29 & 24 & 25 & 11.59 & 11.52 \\
\hline 11. Pearl millet with Nitrogen at $80 \mathrm{~kg} \mathrm{ha}^{-1}$ & - & - & - & - & - \\
\hline 12. Pearl millet + Cowpea (1:1 ratio) with Nitrogen at $80 \mathrm{~kg} \mathrm{ha}^{-1}$ & 28 & 21 & 24 & 11.78 & 11.06 \\
\hline 13. Pearl millet + Greengram (1:1 ratio) with Nitrogen at $80 \mathrm{~kg} \mathrm{ha}^{-1} 2$ & 29 & 23 & 25 & 11.91 & 11.95 \\
\hline SE.m \pm & - & - & 4 & 31.44 & 2.18 \\
\hline $\mathrm{CD}(\mathrm{p}=0.05)$ & - & - & 6 & 41.88 & 2.85 \\
\hline
\end{tabular}


Table.3 Effect of Nitrogen levels on Yield attributes of Cowpea/Greengram

\begin{tabular}{|c|c|c|c|c|c|c|}
\hline \multirow[t]{2}{*}{ Treatments } & \multicolumn{2}{|c|}{ Pods plant ${ }^{-1}$ (No.) } & \multicolumn{2}{|c|}{ Grains pod ${ }^{-1}$ (No.) } & \multicolumn{2}{|c|}{ Test weight $(\mathrm{g})$} \\
\hline & 2017 & 2018 & 2017 & 2018 & 2017 & 18 \\
\hline 1. Pearl millet with Nitrogen at $0 \mathrm{~kg} \mathrm{ha}^{-1}$ & - & - & - & - & - & - \\
\hline 2. Cowpea with Nitrogen at $0 \mathrm{~kg} \mathrm{ha}^{-1}$ & 1 & 2 & 5 & 10 & 9.63 & 7.61 \\
\hline 3. Greengram with with Nitrogen at $0 \mathrm{~kg} \mathrm{ha}^{-1}$ & 13 & 16 & 8 & 12 & 2.07 & 2.15 \\
\hline 4. Pearl millet + Cowpea (1:1 ratio) with Nitrogen at $0 \mathrm{~kg} \mathrm{ha}^{-1}$ & 1 & 1 & 4 & 9 & 6.50 & 7.44 \\
\hline 5. Pearl millet + Greengram (1:1 ratio) with Nitrogen at $0 \mathrm{~kg} \mathrm{ha}^{-1}$ & 11 & 12 & 7 & 11 & 1.93 & 1.97 \\
\hline 6. Cowpea with Nitrogen at $20 \mathrm{~kg} \mathrm{ha}^{-1}$ & 2 & 3 & 9 & 13 & 11.67 & 8.88 \\
\hline 7. Greengram with Nitrogen at $20 \mathrm{~kg} \mathrm{ha}^{-1}$ & 14 & 30 & 9 & 13 & 2.25 & 2.50 \\
\hline 8. Pearl millet with Nitrogen at $40 \mathrm{~kg} \mathrm{ha}^{-1}$ & - & - & - & - & - & - \\
\hline 9. Pearl millet + Cowpea (1:1 ratio) with Nitrogen at $40 \mathrm{~kg} \mathrm{ha}^{-1}$ & 1 & 1 & 6 & 11 & 10.2 & 7.71 \\
\hline 10. Pearl millet + Greengram (1:1 ratio) with Nitrogen at $40 \mathrm{~kg} \mathrm{ha}^{-1}$ & 11 & 19 & 8 & 11 & 1.57 & 2.30 \\
\hline 11. Pearl millet with Nitrogen at $80 \mathrm{~kg} \mathrm{ha}^{-1}$ & - & - & - & - & - & - \\
\hline 12. Pearl millet + Cowpea (1:1 ratio) with Nitrogen at $80 \mathrm{~kg} \mathrm{ha}^{-1}$ & 1 & 2 & 5 & 12 & 10.48 & 7.89 \\
\hline 13. Pearl millet + Greengram ( $1: 1$ ratio) with Nitrogen at $80 \mathrm{~kg} \mathrm{ha}^{-1}$ & 10 & 23 & 8 & 11 & 1.83 & 2.35 \\
\hline SE.m+ & 1 & 3 & 2 & 2 & 1.44 & 1.35 \\
\hline $\mathrm{CD}(\mathrm{p}=0.05)$ & 2 & 4 & 2 & 2 & 1.88 & 1.76 \\
\hline
\end{tabular}


The data from 2018 revealed a similar trend in the maximum number of grains per pod. It was found to be highest in the plots where nitrogen was applied at $20 \mathrm{~kg} \mathrm{ha}^{-1}$ in the pure stand of cowpea $\left(\mathrm{T}_{6}\right)$ and greengram $\left(\mathrm{T}_{7}\right)$. It was closely followed by intercropped plot of cowpea with nitrogen applied at $80 \mathrm{~kg} \mathrm{ha}^{-1}$ $\left(\mathrm{T}_{12}\right)$, pure crop of greengram with no nitrogen applied $\left(\mathrm{T}_{3}\right)$, intercropped plots of greengram with nitrogen applied at $0\left(\mathrm{~T}_{5}\right), 40$ $\left(\mathrm{T}_{10}\right)$ and $80\left(\mathrm{~T}_{13}\right) \mathrm{kg} \mathrm{ha}^{-1}$, intercropped plots of cowpea $\left(\mathrm{T}_{9}\right)$ applied with nitrogen at $40 \mathrm{~kg}$ $\mathrm{ha}^{-1}$ and were statistically at par with $\mathrm{T}_{6}$ and $\mathrm{T}_{7}$.

In the year 2017, it can be observed that the highest test weight (Table 3) was recorded in the plots of cowpea. Bolder and heavier seeds of cowpea were registered in the pure crop of cowpea with nitrogen applied at $20 \mathrm{~kg} \mathrm{ha}^{-1}$ $\left(\mathrm{T}_{6}\right)$. Next in the sequence was in the intercropped plots of cowpea with nitrogen applied at $80\left(\mathrm{~T}_{12}\right)$ and $40\left(\mathrm{~T}_{9}\right) \mathrm{kg} \mathrm{ha}^{-1}$ which were statistically at par with $\mathrm{T}_{6}$. In 2018 , it is revealed that maximum test weight was recorded in cowpea pure crop $\left(\mathrm{T}_{6}\right)$ with nitrogen at $20 \mathrm{~kg} \mathrm{ha}{ }^{-1}$. There was no significant different among the treatments of cowpea plots at different nitrogen levels. During both the experimental years, the test weight of greengram showed no statistical difference between the different treatment combinations of greengram.

\section{Acknowledgements}

This experiment was carried out successfully during both the years with the co-operation of the Advisor, field manager and other students hailing from the department.

\section{References}

Choudhary, R.A. 2009. Intercropping in pearlmillet [Pennisetum glaucum (L.) R. Br. Emend. Stuntz] with pluse crops in rainfed conditions. M. Sc. (Agri.) Thesis. Sardarkrushi nagar Dantiwada Agricultural University.

Gomez, K.A., and Gomez A.A. 1984.Statistical Procedures for Agricultural Research (1st Edition), John Wiley and Sons, Wiley and Sons, Wiley Inter Science Publication, New York, USA. 680.

Karanjikar, P.N., Arshewar, S.P., Takankhar, V.G., and Waghmare, Y.M. 2018. Effect of Nitrogen and Zinc on Growth, Yield and Economics of Pearl Millet (Pennisetum glaucum L.). International Journal of Current Microbiology and Applied Sciences. 6: 2246-2253.

Malik, C.P., and Srivastava, A.K. 1982.Text Book of Plant Physiology. Kalyani Publishers, New Delhi. Pp. 442.

Ofori, F., and Stern, W.R. 1987. Cereal \pm legume intercropping system. Advances in Agronomy. 41: 41-90.

Reddy, M.S., and Willy, R.W. 1981. Growth and resource use studies in an intercrop of pearlmillet/groundnut. National Symposium, Indian Society of Agronomy, CSSRI, Karnal, 3-5 April, 1980, New Delhi

Swaminathan, M.S. 1998.Crop production and sustainable food security. In Chopra V. L., Singh R. B. and Verma A. (eds). Crop Productivity and Sustainability Shaping the Future. Proceedings of the Second International Crop Science Congress, New Delhi, India, pp. 3-18.

\section{How to cite this article:}

Jaya Prathiksha, G. and Joy Dawson. 2019. Effect of Intercropping and Nitrogen Levels on the Growth Parameters of Legumes and Pearlmillet (Pennisetum typhoides L). Int.J.Curr.Microbiol.App.Sci. 8(09): 440-447. doi: https://doi.org/10.20546/ijcmas.2019.809.053 